\title{
Stability analysis of wheat (Triticumaestivum L.emThell) genotypes under different eco-systems
}

\author{
R. K. Gupta ${ }^{1 *}$ and Rashmi Nigam ${ }^{2}$ \\ ${ }^{1}$ Department of Genetics and Plant Breeding, J.V. College, Baraut (Baghpat) U.P., India \\ ${ }^{2}$ Department of Plant Pathology, J. V. College, Baraut (Baghpat) U.P., India \\ *Email: rajeshkumargupta.jvc@gmail.com
}

\begin{abstract}
Stability analysis of 15 different genotypes of wheat was evaluated in three environments. The three environments were artificial created by changing the dates of sowing i.e. timely sown, late sown and very late sown condition, irrigation and fertilizer levels. Observation were recorded for ii characters viz; Days to heading, days to maturity, plant height, peduncle length, No. of productive tillers per plant, spike length, No. of spikelets per spike, No. of grains per spike, 1000- rain weight, grain yield per plant and harvest index. Mean performance between genotypes and environments were significant indicating substantial variability among genotypes and environments for all the characters except peduncle length and spike length. Combined effect of genotypes and environment was significant for all the traits except peduncle length and spike length. The linear effect of environment for stability was significant for the characters but interaction of genotypes into linear environmental effect was highly significant for all the characters except spike length and peduncle length. The estimated value showed deviation pooled over the entire environment exhibited that all the characters were highly significant except peduncle length and spike length. Pooled analysis of variance was highly significant differences among the genotypes and environment for all the traits except for peduncle length and spike length for all three environments.
\end{abstract}

Key words: Stability, irrigation, tillers, environment.

Paper cited: Gupta, R.K. and Nigam, R. (2018). Stability analysis of Wheat (Triticumaestivum L.emThell) Genotypes under different Eco-systems. South Asian Journal of Food Technology and Environment, 4(2): 717-721.

\section{Introduction}

Wheat is the dominant grain of world commerce. It constitutes the major food for millions and millions of people on this planet; occupying the foremost position among the cereal crops of the world. Among the cereals, wheat accords a place of pride because of vast acreage covered in its cultivation, its nutritional value and its association with some of the earliest and most important civilization of the world. The performance of a variety is the function of its genotypes and environmental factors. Therefore, there is needed to make efforts in stabilizing their varietal performance under varying environmental and management conditions. The failure of a genotype to give differential phenotype performance when tested under different environment is the relaxation of the genotype environment interaction. It reduced association between phenotypic and genotypic value may cause selection from one environment to performance poorly in other, forcing plant breeder to examine phenotypic stability. The breeder's objective should be to produce genotypes that are better adapted over range of environment.

In order, to evolve the stable and highly desirable variety of wheat for different ecosystem. Therefore, genotypes testing under different environment for yield and few quality traits has been found to be highly effective and useful (Gupta et al., 2009, Ahmad et al., 2001 \& 2004; Gill et al., 1984; Rajput, 1984; Kishore et al., 1988; Ahmad and Kumar, 1989; Singh and Ahmad, 1991; Zakerin, 1993). There are a number of models (Finley and Wilkinson, 1963; Eberhart and Russell, 1966; Perkins and Jinks, 1968) based on different parameters which have better resolving power among the genotypes for testing stability.

\section{Materials and Methods}

The experimental material consisted 15 genotypes of wheat i.e. HD2329, PBW343, 
UP2338, UP2425, K9107, K9006, RAJ3077, HUW234, HW147, HD2733, AKDW4155, AKDW4008, JKW8, JKW15 and DBW14 were sown in a randomized block design with three replication in three environments during 2012-13 at research farm of J.V. College, Baraut (Baghpat) under different date of sowing i.e. Timely sown, Late sown and Very Late sown conditions, irrigation and fertilizer levels. Each genotype was planted in a plot having a gross area of $3 \mathrm{~m} \times 0.92 \mathrm{~m}$ with 4 rows at 18 inch apart in timely, late and very late sown condition. The recommended cultural and agronomic practices were followed to raise the crop. Five random plants/ plot/replication were labeled and observations were recorded for eleven characters viz; Days to heading, days to maturity, plant height, peduncle length, No. of productive tillers per plant, spike length, No. of spikelets per spike, No. of grains per spike, 1000- rain weight, grain yield per plant and harvest index. The data were subjected to analysis of stability as per the method proposed by Eberhart and Russell (1966).

\section{Result and Discussion}

Analyses of variance for fifteen genotypes at genotypic level for few characters were significant at all three environment locations (Table 1). At $\mathrm{L}_{1}$ location, days to 75 per cent flowering (48.36), days to maturity (0.039), plant height (19.52), number of productive tillers per plant (398.03), spike length (0.36), number of spikelets per spike $(0.035)$, number of grains per spike (12.12), 1000- grain weight (15.38), grain yield (10.41) and harvest index (4.94) were significant. At $\mathrm{L}_{2}$ location, all the characters exhibited significant variances except days to 75 per cent flowering (8.75) and number of spikelets per spike (0.007). Among these number of grains per spike (9.75), 1000- grain weight (7.73) and grain yield per plant (4.61) showed significant variances at genotypic level, rest traits were highly significant in respect of estimated variances $\left(\delta \mathrm{g}^{2}\right)$. The variances at $\mathrm{L}_{3}$ location for days to 75 per cent heading (26.54), days to maturity (0.041), plant height (16.95), number of productive tillers (471.17), spike length (0.40), number of spikelets per spike (0.012), number of grains per spike (10.25), grain yield per plant (10.70) and harvest index (2.52) were significant. On the pooled basis over locations, the days to 75 per cent of heading, plant height and number of productive tillers were highly significant.
The variances at phenotypic level as estimated and revealed location wise performances. At $\mathrm{L}_{1}$ location the days to 75 per cent flowering (49.05), number of productive tillers per plant (673.46), 1000- grain weight (16.49) and harvest index (5.94) were highly significant while days to maturity (0.051), plant height (39.27), spike length (0.55) and grain yield (13.94) were significant. Non-significant performances for peduncle length, number of spikelets per spike and number of grain per spike were observed. $\mathrm{L}_{2}$ location revealed highly significant differences for number of productive tillers (819.72) and number of spikelets per spike $(0.170)$ in this study. Days to maturity $(0.070)$, spike length (0.50) and 1000-grain weight (9.93) exhibited significant variance at phenotypic level. At $\mathrm{L}_{3}$ location highly significant variance was confined to number of productive tillers (943.91), number of spikelets per spike (0.210) and number of grains per spike (11.20). On the other hand, days to 75 per cent flowering (29.12), days to maturity (0.057), spike length (0.60), grain yield (14.10) and harvest index (3.33) were significant.

The pooled analysis of variance for stability (mean sum of square) for eleven characters in 15 genotypes of wheat (Triticumaestivum). The biometrical analysis of all the three locations exhibited character wise differences individually and in interaction (Table $2)$. The genotypes showed highly significant differences among all the characters. The significant environmental effect was also observed on all the traits. The interaction of genotypes into environment showed highly significant for all the characters except peduncle length and spike length. Combined effect of genotypes and environment was significant for all the traits except peduncle length and spike length. The linear effect of environment for stability was significant for the characters but interaction of genotypes into linear environmental effect was highly significant for all the characters except spike length and peduncle length. The estimated value showed deviation pooled over all the locations exhibited that all the characters were highly significant except peduncle length and spike length. Pooled analysis of variance revealed highly significant differences among the varieties and environment for all the traits except for peduncle length, and spike length for all three $L_{1}, L_{2}, L_{3}$ locations. 
Table 1: Analysis of variance for pooled data over three locations for eleven characters of 15 genotypes of wheat (Mean sum of squares

\begin{tabular}{|c|c|c|c|c|c|c|c|c|c|c|c|c|}
\hline 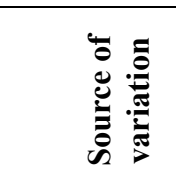 & d. $f$. & $\begin{array}{c}\text { Days to } \\
75 \% \\
\text { heading }\end{array}$ & $\begin{array}{c}\text { Days to } \\
\text { maturity }\end{array}$ & $\begin{array}{c}\text { Plant } \\
\text { height } \\
\text { (cm) }\end{array}$ & $\begin{array}{c}\text { Pedunc } \\
\text { le } \\
\text { length } \\
(\mathrm{cm})\end{array}$ & $\begin{array}{c}\text { Number of } \\
\text { productive } \\
\text { tillers per } \\
\text { plant }\end{array}$ & $\begin{array}{c}\text { Spike } \\
\text { length } \\
\text { (cm) }\end{array}$ & $\begin{array}{c}\begin{array}{c}\text { Number } \\
\text { of } \\
\text { spikelets }\end{array} \\
\text { per spike }\end{array}$ & $\begin{array}{c}\text { Number } \\
\text { of grain } \\
\text { per spike }\end{array}$ & $\begin{array}{l}\text { 1000- } \\
\text { Grain } \\
\text { weight }\end{array}$ & $\begin{array}{c}\text { Grain } \\
\text { yield per } \\
\text { plant }\end{array}$ & $\begin{array}{c}\text { Harvest } \\
\text { index }\end{array}$ \\
\hline Locations & 2 & $160.25^{* *}$ & $0.121^{* *}$ & $108.35^{* *}$ & $6.29^{*}$ & $127.37 * *$ & $8.60 * *$ & $0.23 * *$ & $9.68 * *$ & $28.75^{* *}$ & $89.35 * *$ & $36.22 * *$ \\
\hline Replications & 2 & 45.50 & 0.016 & 4.82 & 0.86 & 19.70 & 0.86 & 0.015 & 0.62 & 0.31 & 1.65 & 10.31 \\
\hline LxR & 4 & $14.33^{* *}$ & $0.117^{* *}$ & 1.35 & $2.91^{* *}$ & $49.84^{* *}$ & $1.65^{* *}$ & $0.093^{* *}$ & $18.45^{* *}$ & $29.94 * *$ & $52.08^{* *}$ & $8.88^{* *}$ \\
\hline Treatments & 14 & $72.99 * *$ & $4.080^{* *}$ & $13.50^{* *}$ & $9.30^{* *}$ & $271.63^{* *}$ & $11.01^{* *}$ & $1.587^{* *}$ & $16.45^{* *}$ & $19.63^{* *}$ & $207.80^{* *}$ & $73.53^{* *}$ \\
\hline LxT & 28 & $56.46^{* *}$ & $0.111^{* *}$ & $11.24 * *$ & $1.55^{* *}$ & $311.72^{* *}$ & $1.11^{* *}$ & $0.045^{* *}$ & $12.35^{* *}$ & $25.38^{* *}$ & $17.28^{* *}$ & $34.23 * *$ \\
\hline Error & 84 & 511.52 & 0.018 & 0.95 & 0.82 & 701.09 & 0.33 & 0.023 & 4.65 & 3.99 & 9.45 & 2.39 \\
\hline$\delta_{g}^{2}$ & & 13.42 & 0.007 & 0.45 & 0.32 & 77.53 & 0.12 & 0.007 & 1.89 & 2.09 & 2.61 & 0.55 \\
\hline$\delta_{1}^{2}$ & & 27.11 & 0.447 & 27.23 & 0.88 & 279.99 & 1.14 & 0.172 & 14.20 & 38.60 & 29.11 & 61.20 \\
\hline$\delta_{\mathrm{gl}}^{2}$ & & 16.98 & 0.031 & 1.35 & 0.30 & 85.70 & 0.26 & 0.007 & 2.95 & 7.13 & 4.45 & 1.56 \\
\hline$\delta_{\mathrm{e}}^{2}$ & & 5.52 & 0.018 & 1.20 & 0.82 & 90.09 & 0.33 & 0.03 & 2.35 & 3.99 & 9.45 & 2.39 \\
\hline
\end{tabular}




\begin{tabular}{|c|c|c|c|c|c|c|c|c|c|c|c|c|}
\hline 苞 & لَّ & $\begin{array}{c}\text { Days to } \\
75 \text { per } \\
\text { cent } \\
\text { heading }\end{array}$ & $\begin{array}{c}\text { Days to } \\
\text { maturity }\end{array}$ & $\begin{array}{l}\text { Plant height } \\
\text { (cm) }\end{array}$ & $\begin{array}{l}\text { Peduncle } \\
\text { length }(\mathrm{cm})\end{array}$ & $\begin{array}{c}\text { Number of } \\
\text { productive } \\
\text { tillers per } \\
\text { plant }\end{array}$ & $\begin{array}{c}\text { Spike } \\
\text { length } \\
(\mathrm{cm})\end{array}$ & $\begin{array}{l}\text { Number of } \\
\text { spikelets } \\
\text { per spike }\end{array}$ & $\begin{array}{c}\text { Number of } \\
\text { grain per } \\
\text { spike }\end{array}$ & $\begin{array}{c}\text { 1000- } \\
\text { Grain } \\
\text { weight }\end{array}$ & $\begin{array}{c}\text { Grain } \\
\text { yield per } \\
\text { plant }\end{array}$ & $\begin{array}{c}\text { Harvest } \\
\text { index }\end{array}$ \\
\hline \multirow[t]{2}{*}{$\delta_{g}^{2}$} & $\begin{array}{l}\mathrm{L}_{1} \\
\mathrm{~L}_{2} \\
\mathrm{~L}_{3}\end{array}$ & $\begin{array}{c}48.36^{* *} \\
8.75 \\
26.54^{* *}\end{array}$ & $\begin{array}{l}0.039^{* *} \\
0.055^{* *} \\
0.041^{* *}\end{array}$ & $\begin{array}{l}19.52^{* *} \\
27.35^{* *} \\
16.95^{* *}\end{array}$ & $\begin{array}{c}0.33 \\
0.77^{* *} \\
0.34\end{array}$ & $\begin{array}{l}398.03^{* *} \\
664.71^{* *} \\
471.17^{* *}\end{array}$ & $\begin{array}{l}0.36^{* *} \\
0.36^{* *} \\
0.40^{* *}\end{array}$ & $\begin{array}{c}0.035^{* *} \\
0.007 \\
0.012^{*}\end{array}$ & $\begin{array}{c}12.12^{* *} \\
9.75^{*} \\
10.25^{*}\end{array}$ & $\begin{array}{c}15.38^{* *} \\
7.73^{*} \\
2.46\end{array}$ & $\begin{array}{c}10.41^{* *} \\
4.61^{*} \\
10.70^{* *}\end{array}$ & $\begin{array}{l}4.94 * * \\
5.89 * * \\
2.52 * *\end{array}$ \\
\hline & $\mathrm{P}$ & $13.42^{* *}$ & 0.007 & $11.25^{* *}$ & 0.32 & $377.53 * *$ & 0.12 & 0.007 & 6.92 & 2.09 & 2.61 & 0.55 \\
\hline \multirow[t]{2}{*}{$\delta_{\mathrm{p}}^{2}$} & $\begin{array}{l}\mathrm{L}_{1} \\
\mathrm{~L}_{2}\end{array}$ & $\begin{array}{c}49.05^{* *} \\
10.72\end{array}$ & $\begin{array}{l}0.051^{*} \\
0.070^{*}\end{array}$ & $\begin{array}{c}39.27 * \\
29.57\end{array}$ & $\begin{array}{l}0.79 \\
1.37\end{array}$ & $\begin{array}{l}673.46^{* *} \\
819.72^{* *}\end{array}$ & $\begin{array}{l}0.55^{*} \\
0.50^{*}\end{array}$ & $\begin{array}{c}0.038 \\
0.170^{* *}\end{array}$ & $\begin{array}{l}3.98 \\
6.67\end{array}$ & $\begin{array}{c}16.49^{* *} \\
9.93^{*}\end{array}$ & $\begin{array}{c}13.94 * \\
7.12\end{array}$ & $\begin{array}{c}5.94 * * \\
0.05\end{array}$ \\
\hline & $\mathrm{P}$ & $18.94 *$ & 0.025 & 18.29 & 1.14 & $\begin{array}{c}1274.62 \\
* *\end{array}$ & 0.45 & 0.030 & 4.90 & 6.08 & $12.06^{*}$ & 2.94 \\
\hline \multirow[t]{4}{*}{$\delta_{e}^{2}$} & $\mathrm{~L}_{1}$ & 0.69 & 0.012 & $30.39^{* *}$ & 0.46 & $275.43^{* *}$ & 0.19 & 0.0030 & $20.25^{*}$ & 1.11 & 3.53 & 1.00 \\
\hline & $\mathrm{L} 2$ & 1.97 & 0.015 & $51.12 * *$ & 0.60 & $155.11 * *$ & 0.14 & 0.010 & $27.32 *$ & 2.20 & 2.51 & $7.73 * *$ \\
\hline & $\mathrm{L} 3$ & 2.58 & 0.016 & $21.33^{* *}$ & 0.64 & $472.74 * *$ & 0.20 & 0.009 & $16.90^{*}$ & 0.67 & 3.40 & 0.81 \\
\hline & $\mathrm{P}$ & 5.52 & 0.018 & $12.51^{*}$ & 0.82 & $90109^{* *}$ & 0.33 & 0.23 & 9.92 & 3.99 & 9.45 & 2.39 \\
\hline
\end{tabular}

L1= Environment first (Timely sown), L2= Environment second (Late sown) and L3= Environment third (Very late sown) 


\section{Conclusion}

Stability analysis of 15 different genotypes of wheat was analyzed at different environment. The results were very significant statistically. The conclusion focused that significant and positive association of grain yield with days to $75 \%$ flowering, days to maturity, number of productive tillers and 1000 grain weight at phenotypic level on pooled basis were quite emphasizing and can be utilized for commercial cultivation. At genotypic level the grain yield was significantly and strongly associated with days to $75 \%$ heading, days to maturity, number of productive tillers, number of grains per spike and 1000 grain weight including harvest index.

\section{References}

1. Ahmad, Z. and Bhatia, R.S. (2004). Adaptability analysis in three successive generations of spring wheat. Proceeding of $2^{\text {nd }}$ National Seminar on Genetics and Wheat Improve. p. 38.

2. Ahmad, Z. and Kumar, J. (1989). Stability for some physiological attributes in bread wheat. Proceeding of National Symposium on Recent Advances in Genetics and Plant Breeding Research in India, VI-45 p. 65.

3. Ahmad, Z. and Srivastava, J.K. (2001). Studies on selection parameters for yield and quality contributing traits in wheat. Proceeding of Diamond Jubilee Symposium on Hundred Years of Post Mendalian Genetics and Plant Breeding: Retrospect and Prospects held at New Delhi from Nov. 6-9.

4. Eberhart, S.A. and Russell, W.A. (1966). Stability parameters for comparing varieties. Crop Science, 6: 36-40.
5. Finley, K.W. and Wilkinson, G.N. (1963).The analysis of adaptation in a plant breeding programme. Australian Journal of Agricultural Research, 14: 742754.

6. Gill, K.S., Bhullar, G.S., Dhillon, B.S. and Khera, A.S. (1984). Comparative evaluation of combining ability and graphical analysis of diallel crosses. Proceeding of Indian National Science Academy, 50: 337-347.

7. Gupta, S., Kumar, R. and Singh, S.K. (2009).Stability of plant height, ear length, peduncle length and spikelets per spike in bread wheat. Indian Journal of Genetics, 79: 222-226.

8. Kishore, Nand, Chaubey, C.N. and Ahmad, Z. (1988). Stability studies for some biochemical attributes in bread wheat. Proceeding of First Symposium on Biochemistry of Photosynthesis and Nitrogen Assimilation, p. 23.

9. Perkins, J.M. and Jinks, J.L. (1968).Environmental and genotypes environmental components of variability III. Multiple lines and crosses. Heredity, 23: 339-356.

10. Rajput, B.P. (1984). Stability parameters for some merit traits in spring wheat $(T$. aestivumL.). Ph.D. Thesis CSAU, Kanpur. (Unpublished)

11. Singh, Y.P. and Ahmad, Z.; (1991). Stability study for some metric traits in spring wheat. Proceeding of Golden Jubilee Symposium on Genetic Research \& Education : Current Trends and the Next Fifty years. Pp. 364-65.

12. Zakerin, A.R. (1993). Studies on genetic stability parameters of breeding value for some metric traits in wheat. Ph.D. Thesis, C.S.A.U., Kanpur (Unpublished).

$\begin{array}{ll}\text { Received } & \text { : Nov., } 2018 \\ \text { Revised } & \text { : Nov., } 2018 \\ \text { Published } & \text { : Dec., } 2018\end{array}$

